\title{
ANALISIS TERHADAP SANKSI KORPORASI PELAKU DUMPING LIMBAH TANPA IZIN PERSPEKTIF HAM
}

\author{
Ali Ibrohim \\ Universitas 17 Agustus 1945 Surabaya \\ E-Mail: armateraya96@gmail.com \\ Budiarsih \\ Universitas 17 Agustus 1945 Surabaya \\ E-Mail: buddyarsih@gmail.com

\section{Slamet Suhartono} \\ Universitas 17 Agustus 1945 Surabaya \\ E-Mail: suhartonoslamet@gmail.com
}

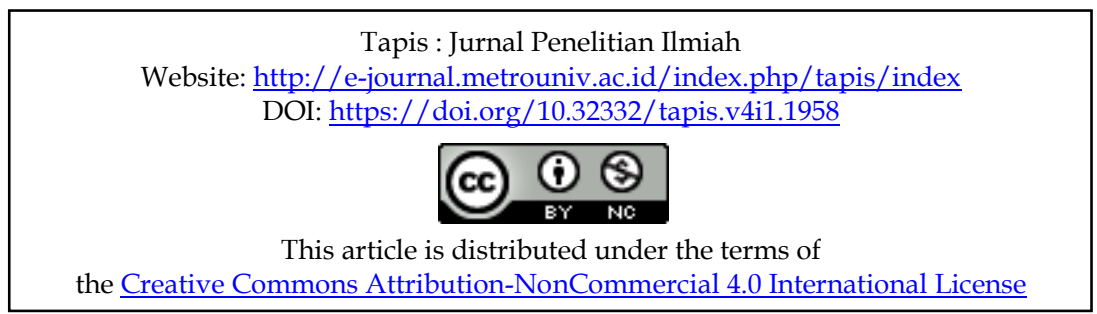

\begin{abstract}
Law Number 23, 2009 concerning Environmental and Management Protection has been running for eleven years. This law still needs a lot of evaluation, especially at the level of implementation or implementation. One of them is related to the sanction for corporations that do environmental damage. There are three types of sanctions that can be given to corporations, namely: civil, criminal and administrative. However, all this time the three did not provide a deterrent effect. As a result, the rights of affected citizens to get a healthy environment are also ignored.

For this reason, this paper focused on how is the Analysis of corporate sanctions of perpetrators of waste dumping without permission viewed from a Human Rights perspective?

This study uses a juridical normative research method, by analyzing secondary data in the form of laws and regulations related to sanctions for corporations that carry out waste dumping without permission.

The results of the study found that the analysis of corporate sanctions for the perpetrators of waste dumping without permission did not represent the protection of human rights for the community. Legal fissures make the corporation can continue its activities and make it possible to do environmental damage again. It is necessary to maximize the application of the highest alternative sanctions by paying attention to human and community rights around the location of waste dumping where the quality of water, air, and soil has deteriorated.
\end{abstract}

Key words: Corporation Sanction, Dumping Corporation, Human Right 


\begin{abstract}
Abstrak
UU Nomor 23 Tahun 2009 tentang Perlindungan dan Pengelolaan Lingkungan Hidup telah berjalan selama sebelas tahun. Undangundang ini masih perlu banyak evaluasi, terutama dalam tataran penerapan atau pelaksanaan. Salah satunya terkait pemberian sanksi bagi korporasi yang melakukan perusakan lingkungan. Ada tiga jenis sanksi yang bisa diberikan kepada korporasi, yakni: perdata, pidana dan administratif. Namun, selama ini ketiganya tidak memberikan efek jera. Akibatnya, hak warga terdampak untuk mendapatkan lingkungan yang sehat juga terabaikan.

Atas dasar hal tersebut tersebut tulisan ini memfokuskan pada pembahasan mengenai bagaimanakah analisis terhadap sanksi korporasi pelaku dumping limbah tanpa izin ditinjau dari perspektif Hak Asasi Manusia?

Penelitian ini menggunakan metode penelitian normatif yuridis, dengan menganalisis data sekunder berupa peraturan perundanganundangan terkait sanksi bagi korporasi yang melakukan dumping limbah tanpa izin.

Hasil penelitian menemukan bahwa sanksi korporasi pelaku dumping limbah tanpa izin belum merepresentasikan perlindungan Hak Asasi Manusia bagi masyarakat. Celah-celah hukum membuat korporasi tetap bisa beraktivitas kembali dan memungkinkan melakukan perusakan lingkungan lagi. Perlu dimaksimalkan penerapan sanksi alternatif yang paling tinggi dengan memperhatikan hak-hak asasi manusia dan masyarakat di sekitar lokasi dumping limbah yang baku mutu air, udara dan tanahnya sudah memburuk.
\end{abstract}

Kata Kunci: Pidana Korporasi, Dumping Limbah, Hak Asasi Manusia

\title{
A. PENDAHULUAN
}

Ada sekitar 13 putusan hakim Pengadilan Negeri dalam kurun waktu 3 tahun terakhir yang berkaitan dengan pidana kasus lingkungan hidup. Beberapa di antaranya adalah kasus pencemaran lingkungan oleh korporasi berupa dumping limbah tanpa izin. Kasus-kasus ini sangat berdampak pada kehidupan masyarakat, bahkan sulit dipulihkan dalam jangka waktu yang panjang. Khusus dalam kasus pencemaran lingkungan yang membuat baku mutu udara, tanah dan air menurun diatur dalam ketentuan pidana UU No 32 tahun 2009 tentang Perlindungan dan Pengelolaan Lingkungan Hidup (UUPPLH). Dalam aturanaturan tersebut, korporasi dapat dihukum dengan tiga jenis sanksi, yaitu : administratif, perdata dan pidana. 
Korporasi memang telah sah menjadi subjek hukum. Karena itu, korporasi bisa dikenai sanksi-sanksi tersebut, baik sebagian atau keseluruhan. Fungsi sanksi ini sendiri adalah untuk memberikan efek jera bagi korporasi yang melakukan kejahatan atau pelanggaran dan dapat mencegah hal tersebut terjadi lagi, baik oleh korporasi tersebut atau korporasi yang lainnnya.

Korporasi sebagai salah satu instrumen pembangunan memang tidak bisa dihindarkan dalam suatu negara. Industri-industri ektraktif memang sangat rawan, terutama dalam hal pembuangan limbah B3. UU kemudian mengantisipasi dengan berbagai aturan, salah satunya adalah Pasal 60 UUPPLH. Dalam pasal tersebut dikatakan, "setiap orang dilarang melakukan dumping limbah dan/atau bahan ke media lingkungan hidup tanpa izin".

Lalu untuk memperkuat posisi pasal tersebut, pada Pasal 104 UUPPLH ditegaskan terkait hukuman bagi korporasi pembuang limbah tidak sesuai aturan. Pasal tersebut berbunyi :

"setiap orang yang melakukan dumping limbah dan/atau bahan ke media lingkungan hidup tanpa izin sebagaimana dimaksud dalam Pasal 60, dipidana dengan pidana penjara paling lama 3 (tiga) tahun dan denda paling banyak Rp3.000.000.000,00 (tiga miliar rupiah)".

Aturan ini sungguh sangat aneh karena masih memberlakukan hukuman dengan batasan maksimal. Akibatnya, banyak perusahaan yang melakukan dumping limbah tanpa izin dihukum dengan hukuman denda di bawah maksimal. Secara aturan, hakim memang diperbolehkan melakukan hal tersebut, namun aturan ini perlu untuk dievaluasi terutama jika melihat dampak buruk dari pembuangan limbah tanpa izin. Apalagi dikaitkan dengan Hak Asasi Manusia yang tercantum dalam Pasal 28H UUD tahun 1945 tentang hak warga Negara mendapatkan lingkungan yang baik dan sehat.

Permasalahan-permasalahan tersebut yang kemudian diakumulasikan dalam pertanyaan berikut; Bagaimanakah Analisis Terhadap sanksi korporasi pelaku dumping limbah tanpa izin dari perspektif Hak Asasi Manusia?

Penelitian terkait korporasi pelaku dumping limbah tanpa izin pernah dilakukan oleh Yondia Vanensashakeh Soemantri dkk dari Fakultas Hukum Universitas Diponegoro dalam tulisan berjudul Studi Dumping Limbah Tanpa Izin Terkait dan Berdasarkan Putusan Nomor 61/pid.sus/2015/PN.Unr jo Nomor 
162/pid.sus/2016/PT.Smg yang dimuat Jurnal Diponegoro Law Journal. Tulisan yang terbit tahun 2017 ini mengkritisi implementasi penegakan hukum dan pelaksanaan peraturan terkait sanksi dumping limbah tanpa izin oleh perusahaan. Dalam putusan tersebut diputuskan denda untuk perusahaan sebesar $\mathrm{Rp}$ 100.000.000,- (Seratus juta rupiah) yang dianggap tidak sebanding dengan kerusakan lingkungan yang ditimbulkan. Selain itu, hakim juga memutuskan untuk menghukum pelaksana pembuangan limbah tersebut tanpa memberikan hukuman kepada direksi yang menyuruh melakukan pembuangan. Hal ini dianggap tidak sesuai Pasal 55 KUHP tentang menyuruh tindak pidana.

Penelitian terdahulu ini berbeda dengan penelitian yang akan dilakukan penulis. Dalam penelitian ini fokus penulis ada pada kajian Hak Asasi Manusia terhadap aturan sanksi bagi korporasi pelaku dumping limbah tanpa izin. Dalam aturan tersebut sudah ditetapkan adanya hukuman pidana penjara maksimal 3 (tiga) tahun dan denda paling banyak Rp 3.000.000.000,- (Tiga miliar rupiah).

\section{B. KAJIAN TEORI}

Penelitian ini menggunakan metode penelitian normatif yuridis. Penelitian yang menganalisa aturan-aturan mengenai suatu isu hukum tertentu ${ }^{1}$. Penelitian ini bertujuan menemukan pemecahan masalah atas isu hukum tentang sanksi yang paling tepat bagi korporasi pelaku dumping limbah tanpa izin. Metode pendekatan berupa pendekatan perundang-undangan dan konseptual dengan menggunakan analisa dari perspektif Hak Asasi Manusia.

\section{a. Hak Asasi Manusia dan Lingkungan Hidup}

Hak Asasi Manusia berkaitan dengan hukum lingkungan di Indonesia mulai diatur sejak perubahan konstitusi Indonesia pada tahun 2000 melalui amandemen kedua UUD 1945². Hak asasi manusia sebagai hak-hak dasar yang harus dimiliki oleh setiap warga Negara telah memerhatikan persoalan lingkungan hidup. Hak hidup pada Pasal 4 dan 9 UU No 39 Tahun 1999 tentang Hak Asasi Manusia dan UUPPLH adalah bentuk penjabaran dari hubungan hak asasi manusia dan hak lingkungan hidup.

\footnotetext{
${ }^{1}$ Husaini Usman and Purbomo Setiady Akbar, Metodologi Penelitian Sosial (Jakarta: Bumi Aksara, 2004).

2 Titik Triwulan Tutik, Kontruksi Hukum Tata Negara Indonesia Pasca Amandemen UUD 1945 (Jakarta: Prenada media Group, 2011).
} 
Jaminan konstitusi terkait HAM di bidang lingkungan sebagai bukti komitmen Negara atas sebuah kehidupan demokratis penting untuk diterapkan. Indonesia sedang berjuang menjadi negara penjamin hak asasi manusia dengan membuat beberapa undang-undang yang melindungi hak asasi warga negaranya. ${ }^{3}$ Termasuk hak lingkungan hidup.

Indonesia mengikuti perkembangan hukum internasional terkait bisnis dan lingkungan, sehingga bergabung dalam penandatanganan kesepakatan internasional United Nation Guiding Principles on Business and Human Rights ${ }^{4}$. Dalam dokumen tersebut ada 3 (tiga) pilar yang menjadi prinsip-prinsip penegakan Hak Asasi Manusia kaitannya dengan lingkungan hidup dan perusahaan atau korporasi.

1. Kewajiban negara melindungi hak asasi manusia, harus melindungi individu, kelompok dan pihak ketiga, yakni bisnis.

2. Perusahaan harus menghormati hak asasi manusia yang dilindungi oleh dunia internasional.

3. Pemulihan bagi korban terdampak perusakan lingkungan harus diperluas baik dengan cara yudisial ataupun non-yudisial guna menjamin hak asasi manusia.

\section{b. Hukum dan Pembangunan}

Doktrin Hukum dan Pembangunan bertumpu pada tesis klasik Max Weber yang berbunyi :

"The modern capitalist enterprise rests primarily on calculation and presupposes a legal and administrative system, whose functioning can be rationally predicted, at least in principle, by virtue of its fixed general norm, just like the expected performance of a machine" (Max Weber 1978: 1394).

Dalam pandangannya, Max Weber melihat perkembangan kapitalisme di dunia mensyaratkan adanya regulasi atau instrumen hukum dan lembaga hukum untuk melakukan perhitungan (calculability) dan prediksi (predictability) bagi pelaku ekonomi, termasuk korporasi.

\footnotetext{
${ }^{3}$ Madja El Muhtaj, Dimensi-Dimensi HAM Mengurai Hak Ekonomi, Sosila, Dab Budaya (Jakarta: Rajawali Pers, 2008).

4 Laporan Komnas HAM, "Pelanggaran HAM Dan Kasus Lubang Tambang" (Jakarta, 2016).
} 
Era tahun 1950 tesis ini menjadi mazhab hukum di Amerika Serikat bernama Law and Development (Hukum dan Pembangunan). Teori ini kemudian mengalami perkembangan ke dalam tiga periode. Pertama, periode Law and Development State (1950an-1970an) yang menumpukan pertumbuhan ekonomi melalui peran negara. Kedua, periode Law and Neoliberal Market (1980an-1990an) yang dipengaruhi oleh Washington Consensus. Hukum di sini menjadi sarana deregulasi dan privatisasi untuk ekspansi pasar.

Doktrin Hukum dan Pembangunan menjadi bahan perdebatan di kalangan akademisi. Misalnya, David Kennedy menyatakan doktrin tersebut memiliki kontradiksi inheren. Doktrin ini menggunakan pendekatan instrumentalisme hukum yang membuat hukum dimaknai semata-mata sebagai sarana untuk mewujudkan pembangunan dan pertumbuhan ekonomi. Doktrin ini juga menggantungkan diri pada formalisme hukum dalam hal penalaran dan penafsiran guna menjaga kepentingan instrumentalisnya.

\section{c. Hukum Pidana dan Korporasi}

Korporasi menjadi subjek hukum di Indonesia baik dalam hukum perdata maupun pidana. Di Indonesia, korporasi adalah salah satu bentuk subjek hukum. Hal ini seperti dalam teori onrechtmatigedaad yang menjadi inspirasi bagi dunia hukum Indonesia. Dalam teori tersebut, subyek hukum yang dapat melakukan perbuatan hukum dan dimintai pertanggungjawaban bukan hanya perseorangan atau individu. Teori ini dipengaruhi oleh teori perkembangan subyek hukum, yang memasukan subyek hukum korporasi atau badan-badan hukum privat, misalnya Perseroan Terbatas (P.T), Commanditer Venootschaap (C.V.), dan sebagainya. ${ }^{5}$

Dalam hukum pidana ada tujuan pemidanaan. Tujuan pemidanaan yang ingin dicapai ada dua, Prevensi Spesial dan General. ${ }^{6}$ Prevensi Spesial adalah tujuan hukum untuk memberikan dampak langsung kepada pelaku tindak

5 Slamet Suhartono, "Penggunaan Alternatief Dispute Resolution Dalam Penyelesaian Sengketa Antara Masyarakat Dengan Pemerintah (Wacana Mewujudkan Penyelesaian Sengketa Yang Seimbang)," DIH, Jurnal Ilmu Hukum 7, no. 14 (Agustus 2011): 72-84.

${ }^{6}$ Sudarto, Hukum Dan Hukum Pidana (Bandung: Alumni, 2007). 
pidana. Sedangkan Prevensi General adalah dampak yang juga berlaku bagi pelaku maupun mereka yang tidak melakukan tindak pidana (pencegahan).

Sedangkan dalam Pidana korporasi juga mengenal Vicarious liability atau pertanggungjawaban pengganti. Dalam hukum pidana korporasi, Vicarious liability merupakan suatu konsep pertanggungjawaban seseorang atas kesalahan yang dilakukan orang lain 7 .

\section{PEMBAHASAN}

Peraturan perundang-undangan di Indonesia dalam bidang lingkungan hidup dimaksudkan untuk melindungi masyarakat dan lingkungannya. Amanat Pasal 28H UUD tahun 1945 sudah sangat jelas, setiap warga Negara berhak untuk mendapatkan lingkungan yang sehat dan baik. Salah satu produk hukum yang terkenal sebagai implementasi dari amanat tersebut adalah UU Nomor 32 tahun 2009 tentang Perlindungan dan Pengelolaan Lingkungan Hidup (UU PPLH).

Negara tidak hanya melindungi lingkungan hidup melalui UU PPLH dan aturan turunannya, Indonesia juga harus memenuhi target-target Anggaran Pendapatan Negara, salah satunya melalui investasi yang melibatkan korporasikorporasi nasional dan internasional. Hingga kemudian, Pemerintah harus mengkompromikan aturan-aturan lingkungan hidup dan aturan-aturan yang mendukung korporasi. Hal ini kemudian melahirkan konsep Pembangunan berkelanjutan berwawasan lingkungan.

Pembangunan hari ini juga harus memperhatikan kehidupan Negara dan bangsa di masa yang akan datang. Pembangunan itu menaikan mutu hidup masyarakat sekaligus menjaga dan memperkuat lingkungan hidup untuk mendukung pembangunan yang berkesinambungan. ${ }^{8}$ Akan tetapi, ideologi dari korporasi adalah keuntungan yang sebesar-besarnya. Hal ini yang kemudian diantisipasi oleh UU PPLH untuk tetap memperhatikan lingkungan hidup di sekitar operasi korporasi dengan perizinan yang ketat dan pengawasan yang kuat. Salah satu kewajiban perusahaan adalah menyediakan lokasi khusus (smelter) untuk menampung limbah Bahan Berbahaya dan Beracun (B3) agar tidak merusak

${ }^{7}$ Mahrus Ali, Asas-Asas Hukum Pidana Korporasi (Jakarta: PT. Raja Grafindo Persada, 2013).

8 Otto Soemarwoto, Ekologi, Lingkungan Hidup Dan Pembangunan (Jakarta: Djembatan, 2001). 
lingkungan. Selain itu, korporasi yang menghasilkan limbah berbahaya harus memenuhi standar dan prosedur berupa izin sebelum mengolah, membuang atau mendistribusikan limbah tersebut.

\section{a. Analisis Peraturan Terkait Dumping Limbah Tanpa Izin}

Dumping limbah atau pembungan limbah adalah salah satu istilah yang ada dalam UU PPLH. Aturan terakit limbah ini ada pada Pasal 20 ayat (3) yang berbunyi:

"Setiap orang diperbolehkan membuang limbah ke media lingkungan hidup dengan persyaratan:

a. memenuhi baku mutu lingkungan hidup; dan

b. mendapat izin dari Menteri, gubernur, atau bupati/walikota sesuai dengan kewenangannya"

Selain itu dalam Pasal 60 UU PPLH juga diatur terakait larangan membuang limbah tanpa izin: "setiap orang dilarang melakukan dumping limbah dan/atau bahan ke media lingkungan hidup tanpa izin".

Pembuangan limbah telah diatur dengan sangat jelas. Setiap perusahaan yang akan membuang limbah harus mengantongi izin dari pihak terkait. Bagi mereka yang tidak memiliki izin dan dengan semena-mena membuang limbah dengan sembarangan dianggap melanggar Pasal 60 UU PPLH dan dikenai sanksi sesuai dengan Pasal 104 UU PPLH yang berbunyi :

"Setiap orang yang melakukan dumping limbah dan/atau bahan ke media lingkungan hidup tanpa izin sebagaimana dimaksud dalam Pasal 60, dipidana dengan pidana penjara paling lama 3 (tiga) tahun dan denda paling banyak Rp3.000.000.000,00 (Tiga miliar rupiah)." 9

Untuk memperkuat aturan yang ada dalam UUPPLH, dibuatlah Peraturan Pemerintah No 101 tahun 2014 tentang Pengelolaan Limbah B3. Dalam Pasal 238 mengatur mengenai pengawasan bagi setiap orang yang mengumpulkan, mengelola, mengangkut, memanfaatkan dan melakukan dumping limbah B3. Pengawasan ini dilakukan oleh Menteri, Gubernur, Bupati/Walikota dan pihak yang ditunjuk sebagai pelaksana pengawasan tersebut. Mekanisme pengawasan berupa verifikasi aktivitas yang terkait

9 “Undang-Undang Republik Indonesia," accessed May 12, 2020, http://www.jdih.kemenkeu.go.id/fullText/2009/32TAHUN2009UU.HTM. 
dengan limbah B3 yang dilakukan korporasi. Hal ini untuk memastikan tidak adanya penyalahgunaan izin oleh korporasi dalam hal limbah B3.

Peraturan Menteri Lingkungan Hidup No 30 tahun 2009 tentang Tata Laksana Perizinan dan Pengawasan Pengelolaan Limbah B3 serta Pengawasan Pemulihan Akibat Pencemaran Limbah B3. Dalam pasal 23 dijelaskan pengawas ditunjuk oleh Menteri, Gubernur, Walikota/Bupati dengan memerhatikan kemampuan orang yang diberi kepercayaan. Dalam pasal tersebut, pengawas terkait limbah B3 harus telah mengikuti pelatihan khusus. Negara ingin memastikan, orang yang menjadi pengawas benar-benar paham tentang limbah B3 dan juga tatacara pengelolaan yang benar agar tidak sampai menimbulkan perusakan lingkungan yang menciderai masyarakat.

Sebelum aturan ini, ada Peraturan Menteri Lingkungan Hidup No 18 tahun 2009 tentang Tata Cara Perizinan Pengelolaan Limbah B3. Pada Pasal 2 ayat (1) disebutkan, ada beberapa hal terkait limbah B3 yang harus mengantongi izin sebelum dijalankan. Di antaranya adalah : pengangkutan, penyimpanan sementara, pengumpulan, pemanfaatan, pengolahan dan penimbunan. Aktivitas-aktivitas tersebut dalam UUPPLH dianggap termasuk dalam Dumping Limbah yang dijelaskan dalam Pasal 60 dan Pasal 104 UUPPLH.

Tentunya hal ini telah memenuhi prasyarat pembentukan hukum pidana dengan adanya pengaturan tindakan yang dilarang, akibat yang tidak boleh dilakukan dan juga jenis hukumannya. Namun, jika dilihat dari sisi tujuan pemidaan, baik Prevensi Spesial maupun General, tentunya hal ini dikaji lebih jauh dalam pelaksanaannya.

\section{b. Analisis Terhadap Sanksi Korporasi Pelaku Dumping Limbah Tanpa Izin Ditinjau dari Perspektif Hak Asasi Manusia.}

Setiap korporasi yang melakukan dumping limbah tanpa izin dapat dikenai tiga sanksi dalam UUPPLH, yaitu: Pidana, Perdata dan Administrasi. Dalam hal pidana, pertanggungjawaban korporasi atau criminal responsibility adalah proses seseorang mempertanggungjawabkan perbuatannya antara 
salah atau benar. Apabila salah, maka pelaku harus mendapatkan hukuman. ${ }^{10}$ Sanksi bagi korporasi yang melakukan dumping limbah tanpa izin dibatasi hanya sampai 3 tahun penjara dan denda Rp 3 miliar.

Penegakan hukum lingkungan keperdataan lebih menekankan pada penyelesaian mengenai ganti kerugian secara materiil dan tindakan pemulihan fungsi lingkungan serta penjaminan tidak akan terulangnya dumping limbah tanpa izin. Penegakan ini dilakukan melalui gugatan, baik gugatan perseorangan, gugatan perwakilan kelompok, gugatan organisasi lingkungan, atau gugatan pemerintah.

Penegakan hukum lingkungan administrasi adalah dengan dicabutnya beberapa izin oleh pemerintah terhadap perusahaan atau korporasi yang melakukan dumping limbah tanpa izin. Namun, dalam perkara ini penegakan hukum administratif tidak serta merta bisa diterapkan meski ada putusan pidana.

Dari beberapa pemaparan tersebut, sanksi bagi pelaku dumping limbah tanpa izin tergolong ringan. Korporasi hanya dikenai sanksi denda maksimal Rp 3 miliar. Padahal, dalam beberapa kasus biaya pemulihan lingkungan yang tercemari oleh limbah lebih dari nominal tersebut. Jika melihat pada tujuan pemidanaan yang ingin dicapai (Prevensi Spesial dan General). Maka hal ini tidak berdampak langsung kepada seluruh pelaku dumping limbah. Selain itu juga tidak menimbulkan efek jera karena para pelaku bisa sangat berpotensi mengulangi perbuatannya.

Selain menggunakan dua tujuan pemidanaan, pidana korporasi juga mengenal Vicarious liability atau pertanggungjawaban pengganti. Hal inilah yang semestinya juga diberlakukan dalam hukum pidana korporasi dumping limbah tanpa izin. Baku mutu air, tanah dan udara yang terdampak haruslah diperbaiki atau diganti seperti semula, bukan ganti rugi sebagaimana membeli tanah dan rumah.

Aturan pidana dumping limbah ini tentunya juga bagian dari Law and Development State maupun Law and Neoliberal Market. Konsekuensinya, kedua

10 Barda Nawawi Arief, RUU KUHP Baru Sebuah Restrukturisasi/Rekonstruksi Sistem Hukum Pidana Indonesia (Semarang: Pustaka Magister, 2001). 
periode tersebut terakumulasi. Cara pandang pembangunan ekonomi ini menempatkan pelaku usaha sebagai agen pembangunan dan memperoleh perlakukan istimewa dengan aturan pidana yang ringann dan beberapa insentif. Sementara itu, negara bertugas memastikan target-target pertumbuhan ekonomi terpenuhi dengan semakin represif terhadap setiap hal yang dianggap menghambat.

Jika dilihat dari beberapa teori hukum pidana dan juga dipandang dari perspektif Hak Asasi Manusia, ketentuan sanksi bagi korporasi yang melakukan dumping limbah tanpa izin masih terlalu ringan. Semestinya hukuman maksimal dalam ketentuan pidana tersebut dihapuskan dan hukuman yang dijatuhkan sesuai dengan akibat perbuatan yang telah dilakukan, disesuaikan dengan korban atau kerusakan yang ditimbulkan oleh kejahatan yang dilakukan korporasi. Lebih bagus lagi apabila sanksi kumulatif (pidana, perdata dan administrasi) diberikan secara bersamaan kepada korporasi yang melakukan dumping limbah tanpa izin. Agar benar-benar memberikan efek jera dan kesadaran yang tinggi tentang jaminan hak warganegara atas lingkungan yang baik dan sehat. Selain itu juga diberlakukan Vicarious liability atau pertanggungjawaban pengganti.

\section{KESIMPULAN}

Sanksi bagi korporasi yang melakukan dumping limbah tanpa izin sudah ditentukan dalam berbagai aturan. Hanya saja, asas keadilan dan kemanfaatan sanksi tersebut tidak sesuai dengan jaminan Hak Asasi Manusia yang diamanatkan oleh UUD 1945. Karena dampak dumping limbah tanpa izin bisa berakibat fatal. Sedangkan hukuman yang diberikan kepada korporasi dibatasi hanya 3 (tiga) tahun penjara dan denda Rp 3 miliar. Semestinya, sanksi yang diberikan kepada korporasi adalah sanksi kumulatif (pidana, perdata dan administrasi sekaligus). Agar sanksi ini benar-benar sesuai dengan tujuan hukum dan tujuan pemidanaan, yakni memberikan keadilan dan efek jera agar tidak terulang kembali. Sehingga kejahatan terhadap lingkungan berkurang dan jaminan atas lingkungan yang sehat dan baik dapat terwujud.

\section{E. REFERENSI}

Ali, Mahrus. Asas-Asas Hukum Pidana Korporasi. Jakarta: PT. Raja Grafindo Persada, 2013. 
Arief, Barda Nawawi. RUU KUHP Baru Sebuah Restrukturisasi/Rekonstruksi Sistem Hukum Pidana Indonesia. Semarang: Pustaka Magister, 2001.

El Muhtaj, Madja. Dimensi-Dimensi HAM Mengurai Hak Ekonomi, Sosila, Dab Budaya. Jakarta: Rajawali Pers, 2008.

Laporan Komnas HAM. "Pelanggaran HAM Dan Kasus Lubang Tambang." Jakarta, 2016.

Soemarwoto, Otto. Ekologi, Lingkungan Hidup Dan Pembangunan. Jakarta: Djembatan, 2001.

Sudarto. Hukum Dan Hukum Pidana. Bandung: Alumni, 2007.

Suhartono, Slamet. "Penggunaan Alternatief Dispute Resolution Dalam Penyelesaian Sengketa Antara Masyarakat Dengan Pemerintah (Wacana Mewujudkan Penyelesaian Sengketa Yang Seimbang)." DIH, Jurnal Ilmu Hukum 7, no. 14 (Agustus 2011): 72-84.

Tutik, Titik Triwulan. Kontruksi Hukum Tata Negara Indonesia Pasca Amandemen UUD 1945. Jakarta: Prenada media Group, 2011.

“Undang-Undang Republik Indonesia.” Accessed May 12, 2020. http://www.jdih.kemenkeu.go.id/fullText/2009/32TAHUN2009UU.HT M.

Usman, Husaini, and Purbomo Setiady Akbar. Metodologi Penelitian Sosial. Jakarta: Bumi Aksara, 2004. 